\title{
Exploring untapped energy potential of urban solid waste
}

\author{
Barkha Vaish $^{1} \cdot$ Vaibhav Srivastava ${ }^{1} \cdot$ Pooja Singh $^{1} \cdot$ Anita Singh $^{3} \cdot$ \\ Prabhat Kumar Singh ${ }^{2}$ Rajeev Pratap Singh ${ }^{1}$ \\ ${ }^{1}$ Institute of Environment and Sustainable Development, Banaras Hindu University, Varanasi 221005, India \\ ${ }^{2}$ Department of Civil Engineering, Indian Institute of Technology, Banaras Hindu University, Varanasi, India \\ ${ }^{3}$ Department of Botany, University of Allahabad, Allahabad, India
}

Received: 11 January 2016/Revised: 26 April 2016/Accepted: 5 May 2016/Published online: 19 May 2016

(C) Joint Center on Global Change and Earth System Science of the University of Maryland and Beijing Normal University and Springer-Verlag Berlin Heidelberg 2016

\begin{abstract}
There is continuous increase in quantum and variety of waste being generated by anthropogenic activities. Burgeoning amount of waste being generated has potential to harm the environment and human health. Aggravating the problem, ever-increasing energy demand is putting strain on the non-renewable sources of energy and there is huge gap between the demand and supply of energy. This has led the scientific communities to adopt innovative methods to reduce, reuse and recycle them. Therefore, there is an urgent need to minimize the quantity of waste and meet the current demand profile of energy is required; technologies to recover energy from waste can play a vital role in substantial energy recovery and reduction in waste for final disposal; in addition to meet the rising energy requirement. Generating power from waste has greatly reduced the environmental impact and dependency on fossil fuels for electricity generation. Economically also it is an optimal solution for recovery of heat and power from waste. This paper gives an overview of energy potential stored in waste, major available waste-to-energy technologies and also strategic action plan for implementation of these technologies.
\end{abstract}

Keywords Waste to energy · Environment · Nonrenewable sources · Urban · Thermochemical .

Biochemical

$\begin{array}{ll}\text { Abbreviations } \\ \text { AFR } & \text { African region } \\ \text { CNG } & \text { Compressed natural gas }\end{array}$

Rajeev Pratap Singh

rajeevprataps@gmail.com

$\begin{array}{ll}\text { EAP } & \text { East Asia and Pacific region } \\ \text { Gt/yr } & \text { Giga ton per year } \\ \text { HI } & \text { High income } \\ \text { HIC } & \text { High-income country } \\ \text { LCA } & \text { Life cycle assessment } \\ \text { LCR } & \text { Latin America and Caribbean region } \\ \text { LI } & \text { Low income } \\ \text { LMI } & \text { Low-middle income } \\ \text { LPG } & \text { Liquified petroleum gas } \\ \text { MENA } & \text { Middle East and North Africa region } \\ \text { Mtoe } & \text { Million ton oil equivalent } \\ \text { MW } & \text { Megawatt } \\ \text { MW } & \text { Megawatt thermal } \\ \text { OECD } & \text { Organization for Economic Cooperation and } \\ & \text { Development } \\ \text { PJ } & \text { Peta joule } \\ \text { SAR } & \text { South Asia region } \\ \text { TJ } & \text { Terra joule } \\ \text { TWh } & \text { Terawatt hour } \\ \text { UMI } & \text { Upper middle income }\end{array}$

\section{Introduction}

Diverse type of wastes generated by human population living in an urban and industrialized background creates various environmental problems such as green house gases emission into air, water pollution and soil contamination (Ghiani et al. 2014). Currently, the world population is 7.1 billion that generate around 1300 million tonnes/year volume of waste $(1.2 \mathrm{~kg} /$ capita/day $)$ which is mostly 
generated by urban centers of the world. This enormous amount is expected to increase and reach up to 2200 million tonnes/year by the year 2025 (World Bank 2012). Disposal of this huge amount of waste which is complex in nature is becoming the main issue of environmental sustainability due to diminishing landfill spaces. Additionally, the rising population and economic growth will put immense pressure on the demand of energy supply (Guerrero et al. 2013). International energy agency projected that world energy demand will increase to 17 billion tonne oil equivalent by the year 2035 and the carbon dioxide emission is expected to increase from 29 to $43 \mathrm{Gt} /$ yr (Chu and Majumdar 2012) under current waste management facilities. The solution relies on how efficiently and effectively the existing resources are utilized by the masses.

According to waste hierarchy, the best option to dispose waste is to recycle and reuse it. What cannot be reused and recycled should go for energy recovery. Generating energy from waste could provide the best financial and environmental benefits to the society. Waste is turned into usable form of energy in the way of either heat or electricity which can be stored and utilized further. This approach paves the way for utilizing maximum energy that is stored in waste. To the dismay, a large fraction of solid waste in most of the developing countries is disposed off unscientifically in open dumps or landfills that generate gases which is mainly composed of $\mathrm{CH}_{4}$ and $\mathrm{CO}_{2}$. These gases are proven cause of global warming; of which methane has global warming potential of 25 times higher than carbon dioxide (Hegde et al. 2003; Srivastava et al. 2015). If possible efforts are not taken, the situation is going to worsen in the recent decades.

Issues of waste management in parallel to economic development have went through numerous developmental stages to reach the technologies and processes for treatment of waste that are present today, viz. thermochemical and biochemical processes. These treatment facilities provide clean renewable energy that has capacity to reduce waste volume by $90 \%$ (Singh et al. 2011b) and waste mass by $70 \%$ (Kumar 2000). Waste-to-energy treatment plants are primarily designed to reduce the amount of waste and then to extract energy. The most common treatment method is incineration followed by pyrolysis and gasification (Tozlu et al. 2016). The composition of waste decides the technology to be chosen for treatment and energy content in the waste (Ouda et al. 2013). Pyrolysis and gasification generate mixture of chemical products such as gases and oils. These have tremendous potential to be burnt in gas turbines or could be converted into transport fuels. Likewise, for organic fraction of waste biomethanation and fermentation processes are applied (Singh et al. 2011a). However, these technologies are technically immature, still evolving and need technological advancement (Rao et al. 2010).

For successful implementation of the waste-to-energy plants, set of proper objectives with appropriate planning and strategies to be completed in set time frame is to be prepared. Strategic action plan in itself includes policy, technical, financial assistance with research and development associated with each available technology (Brunner and Rechberger 2015). This review article guides that waste-to-energy practices are better waste management tools that depends on number of factors such as waste characteristics, finance availability and environmental aspects. The major goal of this article is to better understand the potential of waste in renewable energy sector, available technologies, economical and technological feasibility and their environmental impact.

\section{Energy demand and supply: current status and future scenario}

Energy security and mitigating its contribution to climate change are two vital challenges experienced by energy sectors to provide a sustainable future (Abbasi and Abbasi 2010; Vaish et al. 2016). Global energy demand is directly influenced by population growth and living standard. Both of which should be balanced to meet out the energy requirement of future generations (Raghubanshi et al. 2013). It is a today's bitter reality that billions of people lack access to basic energy facility such as electricity/ power supply and also depend on traditional use of biomass for cooking purpose (IEA 2010; Hegde et al. 2003). Lack of access to these basic energy services creates a barrier on path of socioeconomic development that must be overcome to achieve UN Millennium Development Goals (IEA 2006, $2008,2010)$. This condition will worsen if further appropriate measures are not taken into consideration. It has been estimated that around 1.4 billion people are devoid of access to electricity and 2.7 billion people depend on traditional use of biomass for cooking purposes in the world in 2009 (Table 1) (IEA 2010), among which 0.8 billion people lack electricity and 1.9 billion people use biomass for cooking in developing Asia in 2009. It is projected that the problem will persist even in 2020 and 1.3 billion people will lack access to electricity. Table 1 shows current status and projections about the number of people without access to electricity and relies on traditional use of biomass.

Current world population is 7.1 billion which is expected to reach 9 billion before 2050. This escalating population size is putting immense pressure on energy resources especially non-renewable. A projection suggest that world energy demand will rise from 12,467 million tons of oil 
Table 1 Current status and projections about the number of people without access to electricity and relying on traditional use of biomass. Source: IEA (2010)

\begin{tabular}{lccc}
\hline Region & $\begin{array}{l}\text { Number of people depending } \\
\text { on traditional use of biomass } \\
\text { for cooking (millions) }\end{array}$ & Number of people lacking access to power supply (millions) \\
\cline { 3 - 4 } & 657 & 587 & 2020 \\
\hline Africa & 653 & 585 & 644 \\
Sub-Saharan Africa & 1937 & 799 & 640 \\
Developing Asia & 855 & 404 & 342 \\
India & 423 & 8 & 2 \\
China & 659 & 387 & 307 \\
Other Asia & 85 & 31 & 16 \\
Latin America & 2679 & 1438 & 1350 \\
Developing countries $^{\mathrm{a}}$ & 2679 & 1441 & 1352 \\
World & & &
\end{tabular}

a Includes Middle East countries

${ }^{\mathrm{b}}$ Includes OECD and transition economies

Fig. 1 World energy demand by source. Mtoe million tons of oil equivalent. Source: IEA (2010)

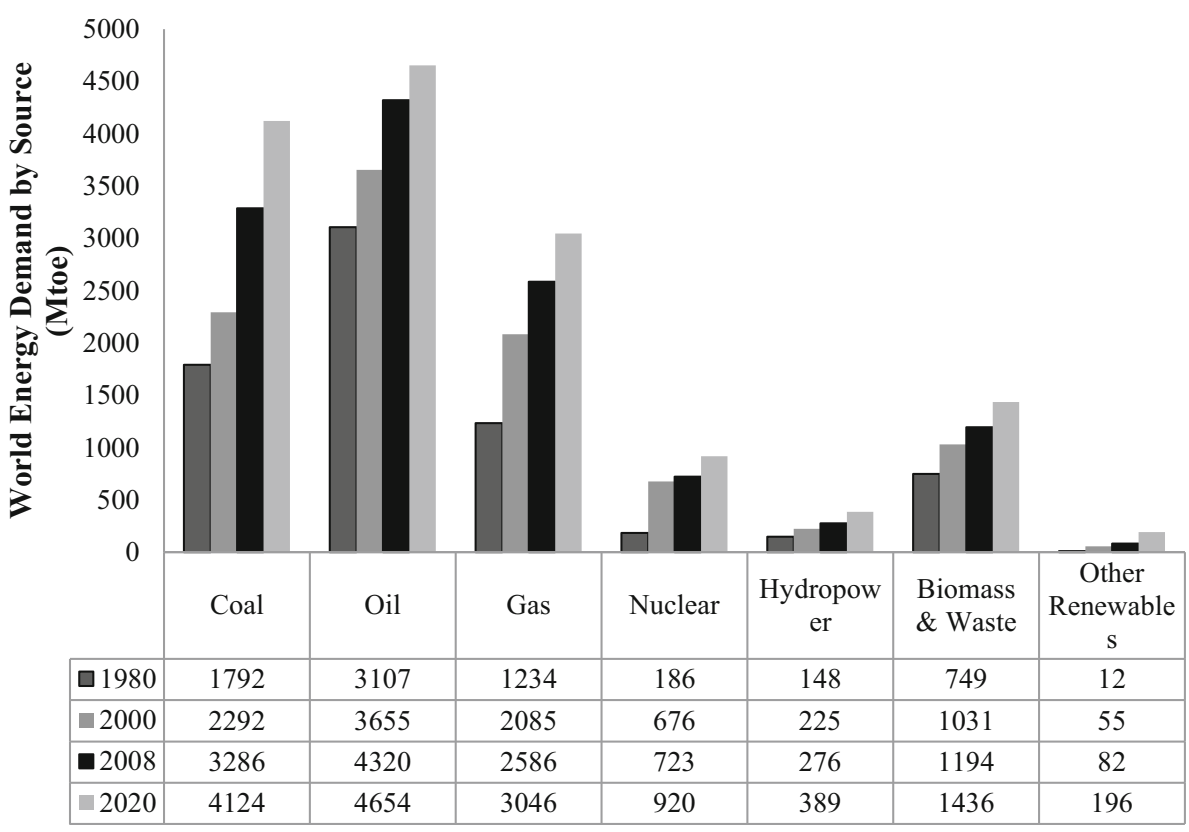

equivalent (Mtoe) in 2008 to 14,765 Mtoe in 2020 (Fig. 1) (IEA 2010). It is believed that developing countries such as India and China will overtake OECD countries as energy consumers and will responsible for over $70 \%$ of this growth.

As per provisional figures of International Energy Agency (2014), the world consumption of total primary energy supply was significantly increased from 6106 Mtoe in 1973 to 13,371 Mtoe in 2012 (Fig. 2).

\section{Waste-to-energy conversion potential at global level}

Nowadays much attention has been paid to alternative use of waste for energy production. This was first implemented by developed countries for measure of energy security and waste management (Kalyani and Pandey 2014). It is helpful from three different perspectives (1) environmental perspective, a number of environmental issues are 
Fig. 2 World total primary energy supply. Mtoe million tons of oil equivalent. Source: IEA (2014)

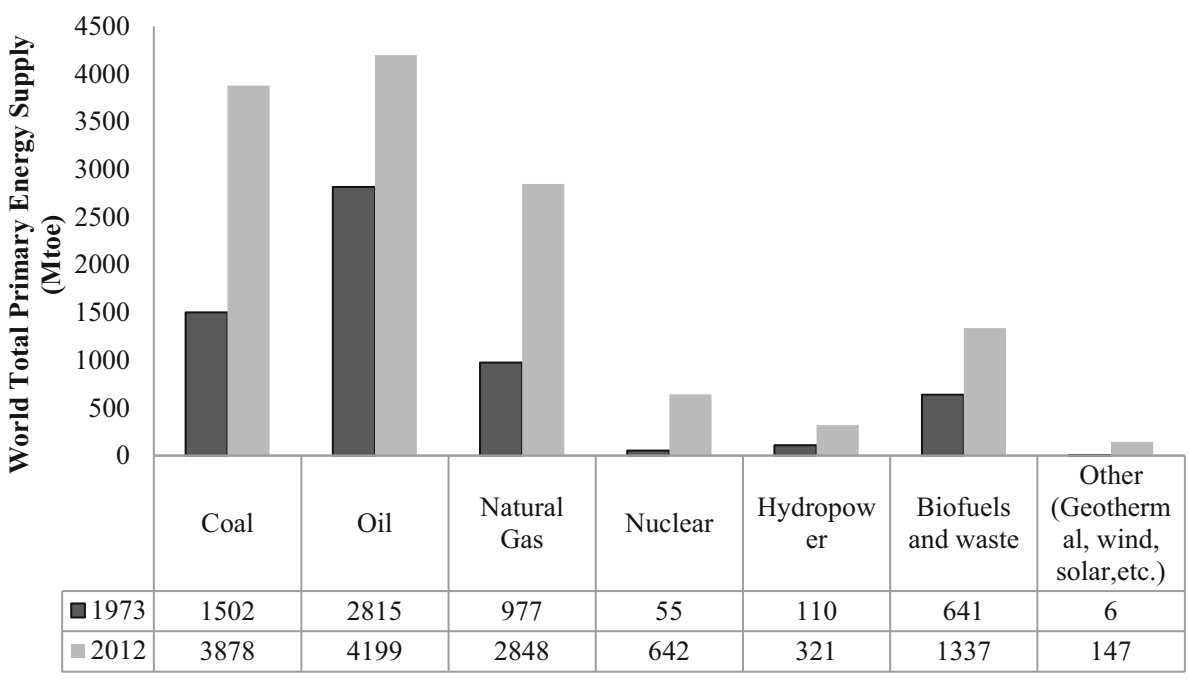

associated with wastes, therefore decreases the amount of wastes finally reaching to the landfill site, (2) energy security, helpful in meeting the gap between energy demand and supply and (3) economic perspective, as waste-to-energy conversion technologies generates monetary benefits to the emerging economies.

\subsection{Global scenario}

An exponential increase in population growth and economic development together with technological advancement has greatly accelerated the MSW generation rate in developing as well as in developed nations (Minghua et al. 2009; Srivastava et al. 2015). As per report of World Bank (2012), the global volume of waste generation is around 1.3 billion tonnes per year in 2012; the figures are expected to rise up to 2.2 billion tonnes per year by 2025 . South and East Asia represents $33 \%$ of total solid waste generated in the world (World Bank 1999). This burgeoning amount of waste and poor waste management practices poses several negative impacts on environment (land, water, air, etc.) and on human health (Scarlat et al. 2015a, b). Therefore, a proper waste management system is required to avoid these problems. There are several options available for managing solid waste; out of which waste-to-energy conversion is one of them. However, factors such as population, socioeconomic status, climatic condition, installation cost, recurrent cost, cost-benefit analysis and life cycle assessment should be taken into consideration prior to its proposal. This section of review investigates the potential of energy production of waste from different parts of the globe. Table 2 shows current population, waste generation and energy potential of different wastes in different regions of the world.

In Africa, energy potential of all wastes generated was 1125 pico-joule (PJ) in 2012 and $2199 \mathrm{PJ}$ in 2025 while the electricity generation potential was 62.5 terrawatt-hours (TWh) in 2012 and 122.2 TWh in 2025 (Scarlat et al. 2015a, b). In Brazil, electricity generation potential from bagasse cogeneration was lying between 62.3 and 93.4 TWh in 2009 (Khatiwada et al. 2012), whereas electricity generation potential of India from bagasse cogeneration is 34 TWh (Purohit and Michaelowa, 2007). In India, biomass energy generation potential is 1460 megawatt (MW) and $226 \mathrm{MW}$ from solid waste and liquid waste, respectively (MNRE 2011). The potential of biomass energy from MSW in China is estimated around $1170 \mathrm{PJ} / \mathrm{yr}$ in 2020 and $3454 \mathrm{PJ} / \mathrm{yr}$ in 2050 (Liu et al. 2011). In Japan, urban waste can generate 500-600 PJ energy representing 2-3\% of total energy consumption (Long et al. 2013). The potential of energy generation from MSW in Malaysia is $400 \mathrm{MW}$, whereas for biogas generation it is 200-250 MW (Oh et al. 2010). Apart from this, palm oil mill effluent which is one of the biggest problems in Malaysia (Embrandiri et al. 2015) has energy potential of 20.23 Mtoe ( $\mathrm{Ng}$ et al. 2012). Likewise, biomass energy potential of Sweden from municipal waste is $56 \mathrm{PJ} / \mathrm{yr}$, whereas from agricultural solid waste it is $237 \mathrm{PJ} / \mathrm{yr}$ (Wiesenthal and Mourelatou 2006; Skovgaard et al. 2008). The above section highlights that there is a tremendous potential of energy generation stored in waste. In addition, to achieve the goals of sustainability developing and developed nations should encourage the use of waste-to-energy conversion technologies, while developing nations in particular should invest more to tap the potential of energy generation from waste.

\subsection{Indian scenario}

In terms of gross domestic productivity (GDP), India is 11th largest economy, whereas it is 3rd in terms of purchase power parity (PPP) (Kalyani and Pandey 2014). It is 
Table 2 Current population, waste generation and energy potential of different wastes generated from different regions of the world

\begin{tabular}{|c|c|c|c|c|c|c|c|c|c|}
\hline Country & Region & Income & Population $^{\mathrm{a}}$ & $\begin{array}{l}\text { Waste }^{\mathrm{a}} \\
\text { generation } \\
\text { (tonnes/day) }\end{array}$ & $\begin{array}{l}\text { Biomass } \\
\text { energy source }\end{array}$ & Units & $\begin{array}{l}\text { Potential } \\
\text { energy/ } \\
\text { bioelectricity }\end{array}$ & By year & References \\
\hline $\begin{array}{c}\text { African } \\
\text { urban } \\
\text { areas }\end{array}$ & AFR & - & - & - & All waste & PJ & $1125-2199$ & 2012-2025 & $\begin{array}{l}\text { Scarlat et al. } \\
\text { (2015a) }\end{array}$ \\
\hline Algeria & MENA & LMI & $19,225,335$ & 23,288 & Biomass & Mtoe & 3.7 & - & $\begin{array}{l}\text { Eddine and Salah } \\
\text { (2012) }\end{array}$ \\
\hline Brazil & LCR & UMI & $144,507,175$ & 149,096 & $\begin{array}{c}\text { Sugarcane } \\
\text { biomass }\end{array}$ & TWh & $62-93$ & 2009 & $\begin{array}{l}\text { Khatiwada et al. } \\
\text { (2012) }\end{array}$ \\
\hline \multirow[t]{2}{*}{ China } & EAP & LMI & $511,722,970$ & 520,548 & $\begin{array}{l}\text { Municipal } \\
\text { waste }\end{array}$ & $\mathrm{PJ} / \mathrm{yr}$ & $1170-3454$ & 2020-2050 & Liu et al. (2011) \\
\hline & & & & & Biogas & & $1258-2517$ & & \\
\hline \multirow[t]{2}{*}{ Denmark } & OECD & $\mathrm{HIC}$ & $4,684,754$ & 10,959 & $\begin{array}{l}\text { Waste } \\
\text { (combustible) }\end{array}$ & $\mathrm{PJ} / \mathrm{yr}$ & $24-30$ & - & Liu et al. (2011) \\
\hline & & & & & Biogas & & $31-40$ & & \\
\hline \multirow[t]{2}{*}{ Finland } & OECD & $\mathrm{HIC}$ & $3,301,950$ & 7,030 & $\begin{array}{l}\text { Municipal } \\
\text { waste }\end{array}$ & $\mathrm{PJ} / \mathrm{yr}$ & 29 & 2025 & $\begin{array}{l}\text { Skovgaard et al. } \\
\text { (2008) }\end{array}$ \\
\hline & & & & & $\begin{array}{l}\text { Agricultural } \\
\text { solid waste }\end{array}$ & & 91 & & $\begin{array}{l}\text { Wiesenthal and } \\
\text { Mourelatou } \\
\text { (2006) }\end{array}$ \\
\hline \multirow[t]{2}{*}{ Germany } & OECD & $\mathrm{HIC}$ & $60,530,216$ & 127,816 & $\begin{array}{l}\text { Municipal } \\
\text { waste }\end{array}$ & $\mathrm{PJ} / \mathrm{yr}$ & 591 & 2025 & $\begin{array}{l}\text { Skovgaard et al. } \\
\text { 2008) }\end{array}$ \\
\hline & & & & & $\begin{array}{l}\text { Agricultural } \\
\text { solid waste }\end{array}$ & & 200 & & $\begin{array}{l}\text { Wiesenthal and } \\
\text { Mourelatou } \\
\text { (2006) }\end{array}$ \\
\hline \multirow[t]{3}{*}{ India } & SAR & LMI & $321,623,271$ & 109,589 & $\begin{array}{l}\text { Municipal } \\
\text { solid waste }\end{array}$ & MW & 1460 & 2011 & MNRE (2011) \\
\hline & & & & & Sewage & & 226 & & \\
\hline & & & & & $\begin{array}{l}\text { Bagasse } \\
\text { cogeneration }\end{array}$ & TWh & 34 & - & $\begin{array}{l}\text { Purohit and } \\
\text { Michaelowa } \\
\text { (2007) }\end{array}$ \\
\hline Japan & OECD & HI & $84,330,180$ & 144,466 & Urban waste & $\mathrm{PJ}$ & $500-600$ & - & Long et al. (2013) \\
\hline \multirow[t]{3}{*}{ Malaysia } & EAP & UMI & $14,429,641$ & 21,918 & MSW & MW & 400 & - & Oh et al. (2010) \\
\hline & & & & & Biogas & & $200-250$ & & \\
\hline & & & & & POME & Mtoe & 20.23 & & Ng et al. (2012) \\
\hline Nepal & SAR & LI & $3,464,234$ & 427 & $\begin{array}{c}\text { Sugarcane } \\
\text { biomass }\end{array}$ & GWh & 209-313 & - & $\begin{array}{l}\text { Khatiwada et al. } \\
\text { (2012) }\end{array}$ \\
\hline \multirow[t]{3}{*}{$\begin{array}{l}\text { Nigeria } \\
\text { (Lagos) }\end{array}$} & AFR & LI & - & - & $\begin{array}{l}\text { Municipal } \\
\text { solid waste }\end{array}$ & MW & 442 & 2012 & $\begin{array}{l}\text { Mohammed et al. } \\
\text { (2013) }\end{array}$ \\
\hline & & & & & Crop residues & $\mathrm{TJ}$ & 697.15 & & \\
\hline & & & & & Animal waste & PJ & 455.80 & & \\
\hline \multirow[t]{2}{*}{ Norway } & OECD & HIC & $3,605,500$ & 10,082 & $\begin{array}{l}\text { Municipal } \\
\text { waste }\end{array}$ & $\mathrm{PJ} / \mathrm{yr}$ & 40 & 2025 & $\begin{array}{l}\text { Statistics Norway } \\
\text { (2008) }\end{array}$ \\
\hline & & & & & $\begin{array}{l}\text { Agricultural } \\
\text { solid waste }\end{array}$ & & 17 & & $\begin{array}{l}\text { Münster and } \\
\text { Meibom (2011) }\end{array}$ \\
\hline Pakistan & SAR & LI & $60,038,941$ & 50,438 & Waste (LFG) & MW & $\sim 83.17$ & - & $\begin{array}{l}\text { Zuberi and Ali } \\
\text { (2015) }\end{array}$ \\
\hline \multirow[t]{2}{*}{ Sweden } & OECD & $\mathrm{HIC}$ & $7,662,130$ & 12,329 & $\begin{array}{l}\text { Municipal } \\
\text { waste }\end{array}$ & $\mathrm{PJ} / \mathrm{yr}$ & 56 & 2025 & $\begin{array}{l}\text { Skovgaard et al. } \\
\text { (2008) }\end{array}$ \\
\hline & & & & & $\begin{array}{l}\text { Agricultural } \\
\text { solid waste }\end{array}$ & & 237 & & $\begin{array}{l}\text { Wiesenthal and } \\
\text { Mourelatou } \\
\text { (2006) }\end{array}$ \\
\hline
\end{tabular}

a World Bank (2012) 
also the second most populated country to witness rapid urbanization and industrialization during last few decades. This puts huge pressure on the nation's resources. Thus, optimal utilization of natural resources and recovering whatever one could get from utilized resources is need of the hour. India with population of 1.2 billion generates 109,598 tonnes per day which is predicted to reach to 376,639 tonnes per day by 2025 (World Bank 2012). This huge amount of waste creates many environmental problems. Consequently, need to be managed in an appropriate manner. Waste-to-energy conversion could prove to be a good option for waste management in India. Table 3 shows statewise energy recovery potential of urban and industrial solid waste in India. Ministry of New and Renewable Energy (MNRE) estimates the existing energy potential of solid waste is $1457 \mathrm{MW}$, whereas $226 \mathrm{MW}$ could be generated from liquid wastes (sewage sludge). However, less than $1.5 \%$ of total potential, i.e., $24 \mathrm{MW}$ has been capitalized till date. Table 4 shows current status of wasteto-energy installed capacity of India. Similarly, a brief overview on some WTE plants set ups in India; their waste treatment capacity and current running status has been illustrated in Table 5.

\section{Available waste-to-energy (WTE) technologies}

With the growing concerns over waste management, climate change and energy security, global market for wasteto-energy (WTE) projects has been increased in the recent years. Need for acquiring local energy demands and finding waste solutions have encouraged new market for waste-toenergy technologies. According to a review by International Solid Waste Association (2002), the global total installed capacity of WTE conversion technologies was 40 million tonnes per year (MT/year) with electrical and thermal energy production of 41 and 110 million gigajoules (GJ) (Themelis 2003), respectively. There are thermal and biological processes that are available for wasteto-energy conversion (Fig. 3). These technologies have
Table 3 Energy recovery potential of urban and industrial solid waste. Source: MNRE (2011)

\begin{tabular}{|c|c|c|c|}
\hline \multirow[t]{2}{*}{ State/Union Territory } & \multicolumn{2}{|c|}{ Energy recovery potential (MW) } & \multirow[t]{2}{*}{ Total (MW) } \\
\hline & $\begin{array}{l}\text { From liquid wastes } \\
\text { (sewage sludge) }\end{array}$ & From solid wastes & \\
\hline Andhra Pradesh & 16 & 107 & 123 \\
\hline Assam & 2 & 6 & 8 \\
\hline Bihar & 6 & 67 & 73 \\
\hline Chandigarh & 1 & 5 & 6 \\
\hline Chhattisgarh & 2 & 22 & 24 \\
\hline Delhi & 20 & 111 & 131 \\
\hline Gujarat & 14 & 98 & 112 \\
\hline Haryana & 6 & 18 & 24 \\
\hline Himachal Pradesh & 0.5 & 1 & 1.5 \\
\hline Jharkhand & 2 & 8 & 10 \\
\hline Karnataka & 26 & 125 & 151 \\
\hline Kerala & 4 & 32 & 36 \\
\hline Madhya Pradesh & 10 & 68 & 78 \\
\hline Maharashtra & 37 & 250 & 287 \\
\hline Manipur & 0.5 & 1.5 & 2 \\
\hline Meghalaya & 0.5 & 1.5 & 2 \\
\hline Mizoram & 0.5 & 1 & 1.5 \\
\hline Orissa & 3 & 19 & 22 \\
\hline Pondicherry & 0.5 & 2 & 2.5 \\
\hline Punjab & 6 & 39 & 45 \\
\hline Rajasthan & 9 & 53 & 62 \\
\hline Tamil Nadu & 14 & 137 & 151 \\
\hline Tripura & 0.5 & 1 & 1.5 \\
\hline Uttar Pradesh & 22 & 154 & 176 \\
\hline Uttaranchal & 1 & 4 & 5 \\
\hline West Bengal & 22 & 126 & 148 \\
\hline Total & 226 & 1457 & 1683 \\
\hline
\end{tabular}


Table 4 Current status of waste-to-energy installed capacity of India. Source: MNRE (2011)

\begin{tabular}{lll}
\hline & $\begin{array}{l}\text { Grid interactive power } \\
\text { (capacities MW) } \\
\text { Waste to power }\end{array}$ & $\begin{array}{l}\text { Off grid/captive power } \\
\text { (capacities MWeq*) } \\
\text { Waste to energy }\end{array}$ \\
\hline Urban & 20.20 & 3.50 \\
Industrial & 53.46 & 72.30 \\
Total & 73.66 & 75.8 \\
\hline
\end{tabular}

* MWeq Mega Watt equivalent

tremendous potential not only to recover energy form waste but also to mitigate energy crisis. But, before selecting appropriate technologies for treatment of waste, number of criteria such as efficiency of the process, operating cost, waste characteristics and environmental impact has to be considered. Following are the brief description of the available technologies and their performance comparison at commercial scale:

\subsection{Biochemical process}

Biochemical processes basically include microbial digestion of organic fraction of waste by enzymes. The end products are essentially methane and/or ethanol and other products. Biochemical conversion processes are among the few processes that are environmental friendly and costeffective toward generation of energy fuel from waste. The most common practices are biomethanation and fermentation which are discussed below.

\subsubsection{Fermentation}

Fermentation is an enzyme-catalyzed chemical process that provides energy yielding pathway by decomposing feedstock assisted by suitable microorganisms (Table 6) under optimal conditions (Hay et al. 2013). The process of fermentation is very common at commercial scale in many developing countries such as Brazil for bioenergy production such as ethanol from sugar and starch crops (e.g., sugar cane, maize, etc.) (McKendry 2002). Likewise, biohydrogen is also being produced by decomposing carbohydrate-rich waste material through this simple technology. Biohydrogen could be produced either by dark fermentation or through photo-fermentation (Ntaikou et al. 2010; Chaubey et al. 2013; Soo et al. 2015). At the end of the fermentation process, alcohol solvents and organic acids are produced apart from hydrogen which can also be commercially utilized instead of being discharged as waste. However, during biohydrogen production, a significant amount of ethanol is generated simultaneously which can be coproduced during the process. Thus, ethanol can serve as an alternative ideal fuel or additives utilized by vehicles (Balat and Balat 2009; Suhaimi et al. 2012) generated at the end of the process.
Utilization of organic fraction of waste is the most viable substrate for ethanol or biohydrogen production due to advantageous mitigation of green house gas emissions, environmental friendliness and its sustainability. However, further purification of ethanol through distillation is an energy-demanding process that produces about $450 \mathrm{~L}$ of ethanol/ton of dry corn (McKendry 2002). The end product after fermentation process can be utilized as feedstock for cattle or can be used in boilers for further gasification method (Coombs 1996; Sen et al. 2016). Till date, there are no proper strategies for improving substrate conversion efficiency of the process. Hence, regulating fermentation parameters and genetic modification of the microbes could represent a promising process for conversion of waste into energy (Huang et al. 2010; Soo et al. 2015).

Wang et al. (2012) examined the LCA for environmental sustainability of process so as to provide a base for decision makers to recognize the main drivers of environmental profiles. This was also supported by Mabee and Saddler (2010). As compared to incineration, fermentation is more environmental friendly and provides environment neutral profiles (Cherubini et al. 2009). Singh et al. (2010) suggested that the best LCA approach for the process is cradle-to-grave approach evaluated by suitable functional units, allocation techniques, appropriate impact categories that depend on the type of organic fraction of feedstock.

\subsubsection{Biomethanation}

Biomethanation is the process of conversion of organic fraction of waste into biogas which is basically composed of methane and carbon dioxide with insignificant amount of hydrogen sulfide gas and other impurities (Tchobanoglous et al. 2004). Microorganisms especially methanogens play pivotal role during the process (Table 6). Biomethanation is an age-old proven technology that involves four stages-hydrolysis, acidogenesis, acetogenesis and methanogenesis (Divya et al. 2015). It is widely used for treating waste with high moisture content approximately around $80-90 \%$. Biogas thus produced can be directly used in gas turbines or it can be upgraded to higher quality gas by the removal of impurities such as carbon dioxide and hydrogen sulfide. The process has 


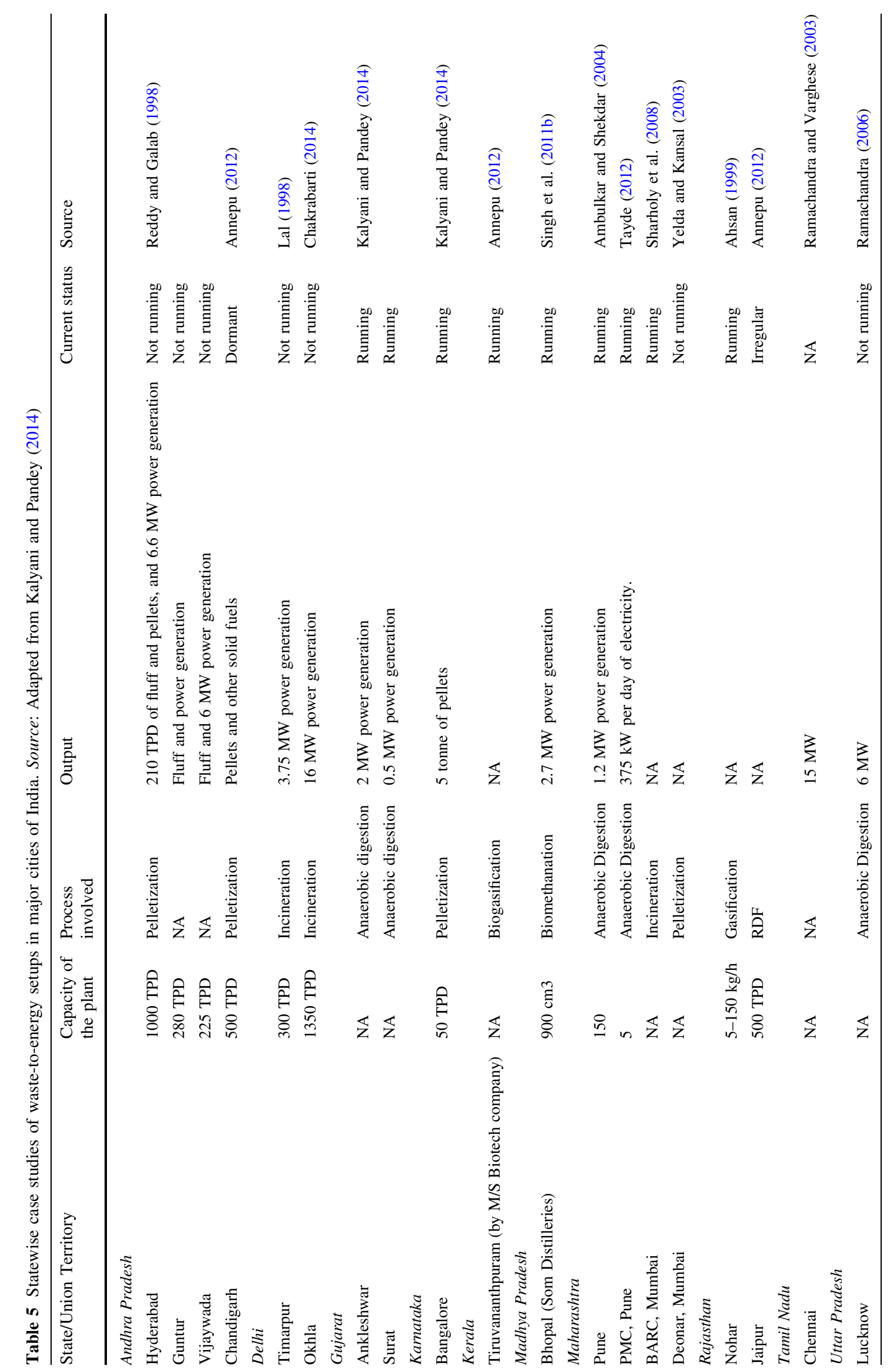




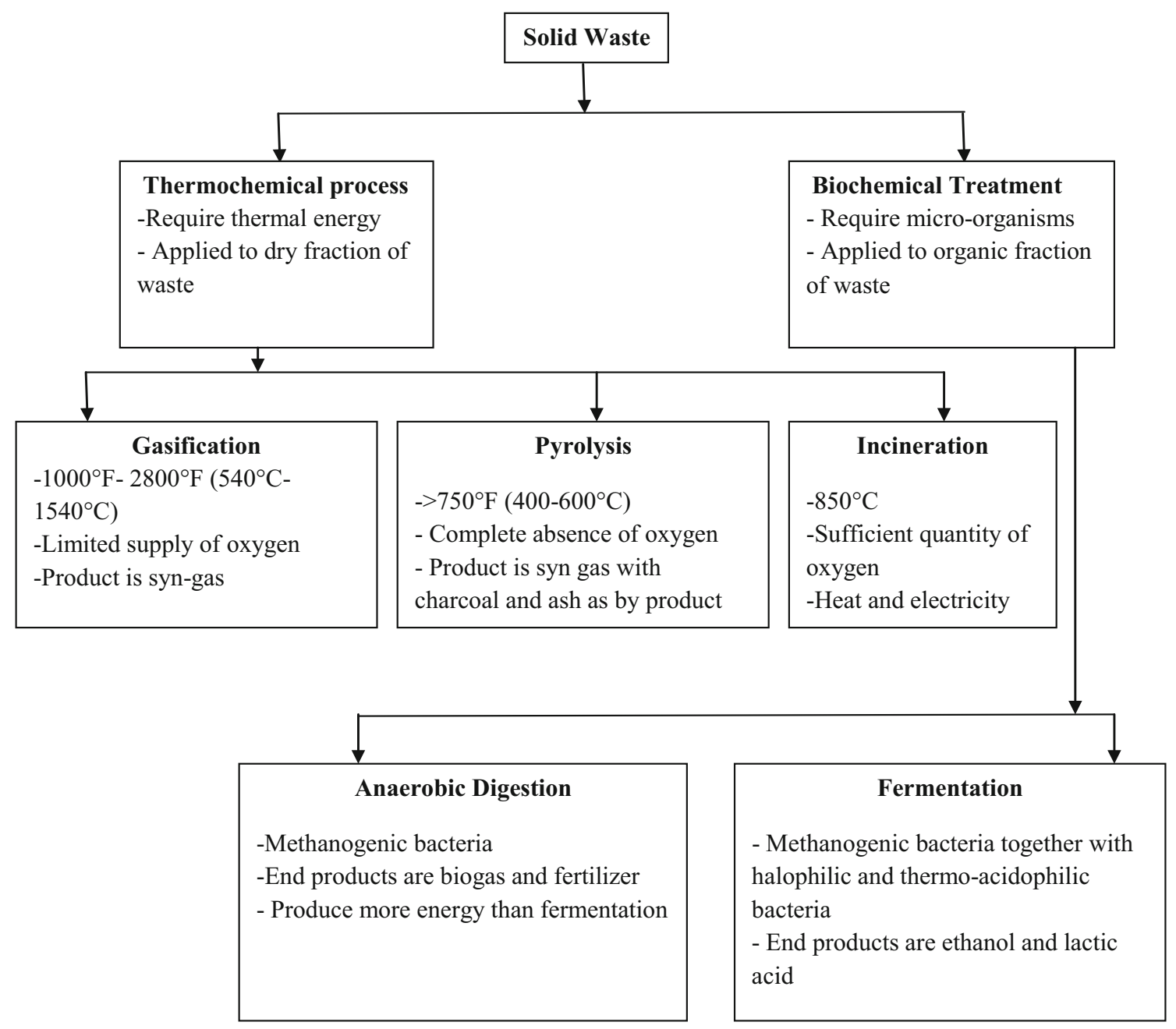

Fig. 3 Thermal and biological processes available for converting waste to energy

Table 6 Different microbes involved in biomethanation and fermentation processes. Source: Sarkar et al. (2012), Khalid et al. (2011) and Trzcinski and Stuckey (2010)

\begin{tabular}{ll}
\hline Microbes & \\
\hline Biomethanation & Fermentation \\
\hline Methanosarcina thermophila & Pleurotus ostreatus \\
Methanoculleus thermophilus & Bacillus macerans \\
Methanobacterium formicicum & Phlebia sp. MG-60 (A marine fungus) \\
Methanobrevibacter sp. & Trichoderma reesei \\
Desulfotomaculum thermobenzoicum & Phanerochaete sordida \\
Methanosarcina barkeri & Pycnoporus cinnabarinus 115 \\
Methanosphaera stadtmanae & Pichia stipitis \\
Methanosaeta concilii & Zymomonas mobilis \\
Thermomonospora & Pachysolen tannophilus \\
Ralstonia & Aspergillus terreus \\
Shewanella & Streptococcus thermophilus \\
\hline
\end{tabular}

promisingly attracted toward itself due to lower environmental impacts, low production cost, production of heat and electricity and complete digestion of organic portion of waste (Oyewole 2010).
Biomethanation technology gained its importance after energy crisis that turned around in 1973 and 1979 (Farrell et al. 2004). Yet, around 50-80 \% failure of the technology was reported in countries such as India, China, Europe, 
Thailand, Russia and Africa throughout the concern period. Although through extensive societal and governmental pressure, digester farms reached a modest success rates (Mwirigi et al. 2014). Feasibility of biomethanation process highly depends on the composition of the feedstock, operating parameters, design of the reactor and microorganisms. Therefore, the overall energy conversion efficiency from biomass to electricity is around 10-16\% (McKendry 2002). It has also been stated that around $20-30 \%$ of the energy generated anaerobically is used up by the process itself (RIS 2005). LCA done by Braun and Laaber (2007) stated that the electrical efficiency of biomethanation could reach as high as $39 \%$. Similarly, LCA performed by Arafat et al. (2015) suggested that biomethanation process has least environmental impact when applied for treating food, paper, and yard waste. They also suggested that incineration is the highest emitter of $\mathrm{CO}_{2}$ followed by biomethanation.

As compared to LPG and CNG, biogas has lower content of methane, i.e., 50-60\%. Even though, due to its manifold benefits, government all over the world are emphasizing on commercializing of biomethanation plants (Eriksson et al. 2016). Technologies present in the past were not efficient enough to improve the quality and quantity of methane gas, and therefore, new and improved science is desired for the above concern (Chaiprasert 2011). Evaluation of microbial dynamics and feedstock characteristics at all the four stages of the process has to be done for exact remedy of the problem and enhancing biogas production (Bhattacharyya et al. 2008).

\subsection{Thermal process}

Thermal process of waste is the most widespread processes that convert waste into energy through thermal breakdown in the form of heat or electricity by any of the thermal conversion technology, viz. pyrolysis, gasification, incineration, etc. They are distinguished by other treatment processes by their high temperature treatment and higher conversion rates (Singh et al. 2011b; Annepu 2012). They allow solid waste reduction in mass to about 70-80 \% and in volume 80-90 \% (Saini et al. 2012). Therefore, significantly smaller landfill space is required for waste disposal (Consonni et al. 2005). Thermal treatment has capability to destroy organic contaminants such as halogenated hydrocarbons (McKay 2002; Buekens and Cen 2011) and can immobilize inorganic contaminants (ISWA 2006; Samaras et al. 2010). Thermal energy conversion plants are environmentally compatible and have the capability to convert solid waste into different energy forms with less environmental impact as when compared to other sources of electricity (US EPA 2003; Rechberger and Schöller 2006). The three main thermal conversion processes widely used are pyrolysis, gasification and incineration that are discussed below.

\subsubsection{Gasification}

Gasification (also known as indirect combustion) is thermal conversion of waste into fuel or synthetic gases that operates at temperature around $1000-2800{ }^{\circ} \mathrm{F}$ $\left(540-1540{ }^{\circ} \mathrm{C}\right)$ with limited supply of oxygen or air (Kalyani and Pandey 2014). It is therefore partial combustion of waste that requires lower amount of oxidant as compared to normal stoichiometric combustion (Arena 2012). The resultant syngas or producer gas is comprised mainly of $\mathrm{H}_{2}, \mathrm{CO}$ and $\mathrm{CO}_{2}$ (with calorific value between 10 and $15 \mathrm{MJ} / \mathrm{m}^{3}$ ) that also contains large amount of incomplete oxidized product which can be utilized in different processes and at different sites as it is easier to handle and to burn (Diblasi 2000). However, the gas has several impurities such as tar, particulate matter, alkali metals, chloride and sulfides (Heermann et al. 2000; Knoef 2005) and thus requires additional gas cleanup equipment.

Gasification is a complex process that depends on the number of parameters such as characteristic of waste provided, type of reactor and operating temperature (Arena and Mastellone 2009). On the basis of oxidation medium used, the process can either be carried out in partial oxidation with limited amount of oxygen or in pure oxygen (air rich in oxygen). The syngas produced after the partial oxidation with air has calorific value ranging between 4 and $7 \mathrm{MJ} / \mathrm{m}_{\mathrm{N}}^{3}$. This value is too low to be considered for use in gas turbines (Arena 2012) when compared to calorific value of natural gas, i.e., $38 \mathrm{MJ} / \mathrm{m}_{\mathrm{N}}^{3}$ (Mastellone et al. 2010). To obtain gas with high calorific value, partial oxidation with air that is enriched with oxygen is done. This process reaches calorific value of around 10-15 MJ/ $\mathrm{m}_{\mathrm{N}}^{3}$. But the cost of production of oxygen in separate units

Table 7 Different pyrolysis processes and their associated parameters. Source: Katyal (2007), Mohan et al. (2006) and Demirbas (2007)

\begin{tabular}{|c|c|c|c|c|c|}
\hline Parameters & Conventional pyrolysis & Vacuum pyrolysis & Flash (rapid) pyrolysis & Carbonization & Pressure carbonization \\
\hline Residence time & $5-30 \mathrm{~min}$ & $2-30 \mathrm{~s}$ & $0.1-2 \mathrm{~s}$ & Hours-days & $15 \mathrm{~min}-2 \mathrm{~h}$ \\
\hline Heating rate & Low & Medium & High-very high & Very low & Medium \\
\hline Temperature $\left({ }^{\circ} \mathrm{C}\right)$ & $550-900$ & $350-450$ & $600-3000$ & $300-500$ & $450-550$ \\
\hline Products & Char, oil, syngas & Oil & Oil, syngas & Charcoal & Charcoal \\
\hline
\end{tabular}




\section{Constituents of bio-oil}

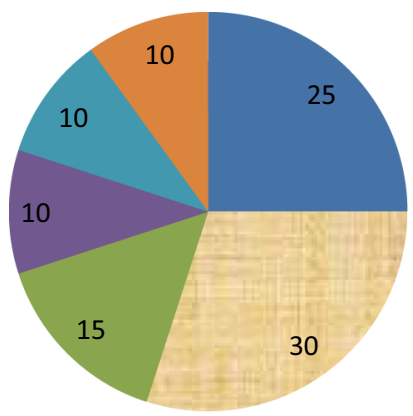

water

- Organic acids

Anhydrosugars

Water insoluble pyrolytic lignin

non-polar hydrocarbons

- Other oxygenated compounds

Fig. 4 Constituent of Bio-oil. Source: Shaw (2006)

is only justified for only very large-scale plants (Arena 2012).

Other important parameters for consideration are residence time of waste, devolatilization, equivalence ratio, cold gas efficiency (CGE), hot gas efficiency (HGE) carbon conversion efficiency, etc. (Ahmad et al. 2016). However, these parameters do not necessarily provide an exhaustive summary of the quality of gas produced by the process. In the present market for waste gasifier, cold gas efficiency (CGE) and specific energy generation are crucial but not sufficient for the assessment of the process (Heermann et al. 2000).

Obtaining energy from waste needs environmental and cost performance analysis through life cycle assessment which forms the basis of decision-making tool and developing strategies for waste management (Khoo 2009). LCA performed by Arafat et al. (2015) for gasification, speculated that electric production efficiency is around $40 \%$ by using gas turbine. The reason is that the gas turbines do not require pre-treatment of the products (Belgiorno et al. 2003). Furthermore, the gasification process has least carbon dioxide emission when applied to wastes such as plastic and yard waste. It has least environmental impact when applied for treating plastic waste (Arafat et al. 2015). This clearly states that the gasification process has advantage over other process in terms of green house gas emissions. According to US Department of Energy Worldwide Gasification Database, the current gasification capacity has now reached up to $70,817 \mathrm{MW}_{\text {th }}$ of syngas output at 144 operating plants with total 412 gasifiers. If this growth continues, the worldwide capacity will reach $122,106 \mathrm{MW}_{\text {th }}$ of syngas by the year 2016 from 505 operating gasifier plants.

Waste gasification provides several potential benefits over direct combustion. (1) Gasification models are modular in nature (they can be adjusted according to the solid waste treatment), (2) strongly limits emission of dioxins and furans, (3) power can be generated at smaller scale (i.e., below $120 \mathrm{kt} / \mathrm{yr}$ ), (4) higher energy conversion efficiency for the fuel gas produced and (5) non-combustible and non-oxidized material is collected at the bottom of the reactor (CEWEP 2011), except for fly ash and some volatile component (Belgiorno et al. 2003; Sharholy et al. 2008; Arena 2012).

\subsubsection{Pyrolysis}

Pyrolysis is another direct thermo chemical decomposition of waste feedstock at elevated temperature around $>750{ }^{\circ} \mathrm{F}$ $\left(400-600{ }^{\circ} \mathrm{C}\right.$ ) in complete absence of oxygen (Demirbas et al. 2011). The end product obtained is syngas that can be converted to liquid hydrocarbons while the by-products are charcoal and ash. Pyrolysis has a promising future for converting waste into higher heating value fuels (Balat 2008). There are different types of pyrolysis technologies that ranges from carbonization to flash (rapid) pyrolysis depending on the operating conditions and feedstock used (Demirbas 2009).

Table 7 summarizes the different types of pyrolysis processes involved in treatment of waste and the parameters that are associated with it.

If the aim is to produce liquid or gaseous products with maximum yield, fast pyrolysis is preferred (Pütün 2002). Fast pyrolysis also called as thermolysis that exposes material/feedstock to high temperature in the absence of oxygen (Thamburaj 2000). It is coupled with gas at higher temperature $(775 \mathrm{~K})$ and tar at lower temperature $(675 \mathrm{~K})$ (Bridgwater 2003). Depending on the feedstock used, fast pyrolysis produces $60-75 \mathrm{wt} \%$ bio-oil and $15-25 \mathrm{wt} \%$ of solid char, in addition to 10-20 wt $\%$ of non-condensable gases (Demirbas et al. 2011). In a study by Sharma and Bakhshi (1993), upgradation of bio-oil was done by the use of HZSM-5 as catalyst at temperature around $613-683 \mathrm{~K}$ in a fixed bed micro-reactor. The result was 19 wt $\%$ of bio-oil with highest concentration of aromatic hydrocarbons around $83 \mathrm{wt} \%$. The same catalyst was used for upgradation of bio-oil from rice husk in sub and super critical ethanol (Peng et al. 2009).

Bio-oil which is the main product of fast pyrolysis can be obtained from variety of feedstock such as forest residue and agriculture waste. Forest residue is mainly used in North America and Europe, and agricultural waste material is mainly utilized in Central and South America, the Caribbean and South Pacific, Australia, Asia and Africa (Mohan et al. 2006). Bio-oil has a lower heating value of $16 \mathrm{MJ} / \mathrm{kg}$ as when compared to diesel $43 \mathrm{MJ} / \mathrm{kg}$ (Brammer et al. 2006). Yield of bio-oil highly depends on amount of cellulose and lignin content of the feed stock used. Composition of bio-oil mainly consisted of 


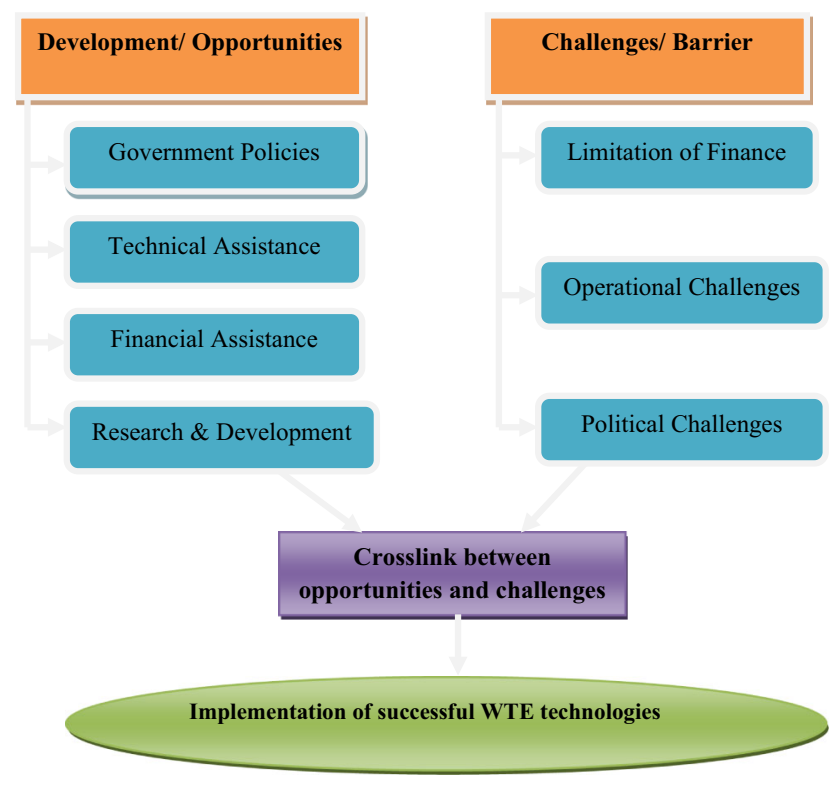

Fig. 5 Strategy for successful WTE Technologies

hydrocarbons, phenols, furans, aldehydes, ketones and ethers (Fig. 4).

However, bio-oil cannot be utilized as a transportation fuel due to high viscosity, water and oxygen content and lower heating value as compared to diesel. Hence, upgrading process to convert it to tangible fuels is done under the process of catalytic hydrogenation and catalytic cracking (Vispute and Huber 2009).

\subsubsection{Incineration}

Incineration is direct thermal treatment of waste at very high temperature around $850{ }^{\circ} \mathrm{C}$ for recovering energy in sufficient quantity of oxygen to oxidize the fuel. Carbon dioxide and water vapor are the major end products of the process (Johnke 2012) in addition to incombustible ash. MSW incineration has gained much importance in recent years due to electricity generation, enhances fuel diversification and significantly reduces the amount of waste for landfilling (Tsai and Kuo 2010). As speculated by Murphy and McKeogh (2006), during incineration $15 \%$ of the input energy is available as electricity. For integrated incineration system, waste from one million people could provide power to 12,400 cars, supply electricity to 30,900 houses and heat to around 15,100 houses (Tsai and Kuo 2010).

LCA by Arafat et al. (2015) showed that incineration process had maximum $\mathrm{CO}_{2}$ emissions as when compared to other process except biomethanation. He also stated that incineration has least environmental impact for textile waste and hence best suited for treating textile waste. In the mid-1980s, Eastern European and Asian cities switched from open dumping to incineration while in Asia, there is limited operational plants due to technological, financial and operational constraints (World Bank Report 1999). A study by Zsigraiová et al. (2009) showed that integrated waste-to-energy plants could mitigate carbon dioxide emission and can balance the incineration cost by the revenue gained by electricity trading. Energy recovery efficiency for incineration varies from 0 to $34 \%$ electricity and 0 to $88 \%$ heat (Astrup et al. 2015). Overall, several studies found that pyrolysis and gasification are better options than incineration in power plants or cement kilns (Bientinesi and Petarca 2009; Nakakubo et al. 2012; Gunamantha and Sarto 2012; Astrup et al. 2015).

\section{Assessment of 3E (energy, economics and environment) of waste-to-energy technologies}

Waste-to-energy conversion technology includes biochemical and thermal treatment of converting waste into usable form of energy (Johri et al. 2011). The utilization of waste mitigates green house gas emissions, waste disposal issue and also generates power (Rigamonti et al. 2016). Currently there are approximately 800 wastes to energy plants operable in around 40 countries of the world; treat around $11 \%$ of waste produced worldwide and generates approximately $429 \mathrm{TWh}$ of power (Richard 2012). Therefore, it is necessary to evaluate the $3 \mathrm{E}$ that involves energy, economics and environmental assessment of the waste for different energy processes.

\subsection{Energy assessment}

International Panel on Climate Change asserted that there will be threefold increase in the energy consumption by the year 2100. In this regard, waste can be converted to energy in the form of heat and electricity. However, energy from biomass will enhance to $50,000 \mathrm{TWh}$ in year 2050; 75,000 TWh in the year 2075 and 89,000 TWh in 2100 (IEA 2006). Due to varying composition of waste, it is very difficult to accurately assess the energy value stored in the waste. However, according to a study by Murphy and McKeogh (2004) of all the available technologies, gasification was proved to be the best in terms of electric production, i.e., approximately around $1083 \mathrm{kWh} / \mathrm{t} \mathrm{MSW}$ and for biogas the value was comparatively low, i.e., $151 \mathrm{kWh} / \mathrm{t}$ of MSW. Likewise for incineration, the electricity production was around $200 \mathrm{kWh} / \mathrm{t}$ (Cheng and $\mathrm{Hu}, 2010$; Panepinto et al. 2015). However, average data on electricity production vary from country to country because of varying composition of waste and different efficiency of 
the technologies being applied to the waste (Fruergaard et al. 2009).

\subsection{Economical assessment}

Economical aspect includes the investment cost, tipping fee and fuel cost associated with each waste-to-energy projects. With the type of technology chosen, the value of tipping fee also changes. It has been calculated approximately that applying waste-to-energy technology could increase the GDP by $0.1 \%$ (Steiner 2010). The process of gasification is most sensitive to change in rate of electricity as compared to incineration. The tipping fee for biomethanation is much cheaper as compared to incineration or gasification (Murphy and McKeogh 2004). However, biomethanation could not be efficiently used for electricity generation but can only be used as transport fuel. Therefore, it can be concluded that the biological processes are economically cheaper than the thermal processes (Gaeta-Bernardi and Parente 2016).

Electricity pricing can be more accurately done with concession in electricity bills, abolishing price ceilings and declining block rate pricing. This would encourage reduction in consumption of energy and increase energy efficiency. If the true rates of electricity with peak and off peak hours are presented on the bill, the customer will use electricity in a more responsible way (Sovacool 2009; Pan et al. 2015). This could prove to be a powerful insight when it comes to planning and decision making for waste-toenergy technologies.

Münster and Meibom (2011) in their study reached the conclusion that after optimization of investments and production of energy, the most economically reasonable technologies are biomethanation of organic fraction of waste, incineration of mixed waste and gasification for refuse derived fuel. On the whole, from economic point of view recycling and biomethanation are best waste management technologies.

\subsection{Environmental assessment}

Environmental assessment of the available technologies is important for the feasibility of the process. Technologies that generate energy from waste have proved that they are no longer a threat to environment (E4Tech 2009; UCR 2009; Dedinec et al. 2015). Generation of energy from biochemical process (biomethanation in particular) has gained a worldwide acceptance (DEFRA 2007); gasification is still in the process of getting recognition by the environmental society as the process is confused with incineration. It must be noted that the low level of oxygen present in the gasification strongly inhibits the formation of dioxin and furans. Waste-to-energy processes extremely save the land area which would otherwise be needed for landfilling of the waste (Arena 2012). Psomopoulos et al. (2009) estimated that waste-to-energy plant treating about $1 \mathrm{Mt} / \mathrm{y}$ of waste for 30 years will require less than $100,000 \mathrm{~m}^{2}$ of land when compared to landfilling that requires about $3,000,000 \mathrm{~m}^{2}$ for disposing $30 \mathrm{Mt}$ of waste. $\mathrm{He}$ also concluded that about 1 toe of $\mathrm{CO}_{2}$ is saved per ton of waste if not disposed by landfilling.

Therefore, all of the available technologies provide different results, and all have the capability to change the waste-to-energy arena. Due to their lower emission into the atmosphere, lower threat to the human health and economic feasibility, they are gaining widespread recognition and increase in number of installation due to complete elimination of waste. Although the investment costs are high, we need to find the promising revenue systems such as government subsidies, electric energy sales, reduction in tipping fee and renewable energy credits for their successful implementation.

\section{Strategies on implementation of WTE technologies (strategic action plan)}

Management of waste is one of the major environmental and socioeconomic challenges for all countries. This includes reduction in waste production and their sustainable management (Pan et al. 2015). The basic steps for proper waste management are prevention, recovery and, finally, disposal. Among different management strategies, conversion of waste to energy (WTE) is one of the most valuable strategies. It includes treatment of any kind of waste to generate energy in the form of electricity, heat or transport fuels (e.g., diesel). With the help of this technology, several kinds of waste such as semi-solid (e.g., thickened sludge from effluent treatment plants), liquid (e.g., domestic sewage) and gaseous (e.g., refinery gases) waste can be utilized to produce different form of energy. There are several projects to convert waste into energy and they require combination of efforts from several different perspectives. Along with future technical developments, including the introduction in the market of alternative processes, it is nowadays crucial to take into account all the social, economic and environmental issues that may occur in the decision-making process of this technology (Scarlat et al. 2015b). The strategies involved in WTE technologies are discussed in detail (Fig. 5).

\subsection{Government policies and their responsibilities}

Government policies should address the challenges of energy security along with the development of WTE sector for the sustainable growth of the society. The attributes of 
government policies include several agendas such as policy formulation, adoption and evaluation of particular technique to achieve the goal of reducing waste. Earlier there were policies that have been categorized as financial, administrative or social policy. During the present scenario, there are integrated policies that cover actions formulated with a multi-disciplinary approach. It is one of the successful ways to accomplish effective and efficient WTE supply chain. Basically, the development and installation of a WTE supply chain require the involvement of owner of the WTE plants, i.e., a governing body, source of energy supply, distribution companies and people that will be affected by the projects directly and indirectly (D'Alisa et al. 2012). Policy makers have to understand the specific issues of the concern area before drafting a guideline.

There is variation in different communities of the world regarding energy demand, local environment, local economy and environmental protection standards. Therefore, it is essential that appropriate policy measures are used to ensure viability and compatibility of project. Sometimes, a policy does not need to enact large overbearing financial mechanisms but instead just needs to simply overcome a few local barriers. For WTE supply chain, a decisionmaking strategy include: supply and demand of contracts, configuration of network such as sourcing, location and capacity of energy production facilities, location of storage facilities and network design, and lastly the ensuring sustainability (Iakovou et al. 2010). Government plays an important role in making policies that brings energy companies and the local communities together.

Depending upon the project cost, a governing body should take help from local government to an international organization. When the market fails, there should be intervention of some changes by government policy makers (White et al. 2013). The different role is played by government such as to evaluate costs and benefits, control assets and resources, require long-term commitments and allocate the development of a waste-to-energy facility with an energy efficient distribution infrastructure (Hawkey et al. 2013). The cost of project can be lowered by linking it with public investment and energy service companies (ESCO) by municipal authorities. When concerned authorities cannot regulate or govern, the projected benefits of a policy cannot be realized (Sarkar and Singh 2010). Comprehensiveness, consistency and flexibility are the three major traits that are necessary for obtaining success in policies. A policy should be clear in its goals. With uncertain goals of policy, there are negative consequences of a collapsed project, whereas perfect goals and actions make the project more feasible. Another object concerning the concept of consistency is the need for policy makers to make changes as minimal and infrequent as possible.
A constantly shifting policy will result in reluctant investors and limited progress during production. In addition, a policy needs to be formulated with precautions making it fit enough to handle changes in the political and economic landscape. A plant and its associated energy distribution network should be able to predict how they would function when changes occur (White et al. 2013). Consequently, a successful WTE supply chain among plants can demonstrate its environmental and economic benefits, as suggested by the national sustainable development policy (Shih et al. 2006).

\subsection{Technical assistance}

The strategic action plan (SAP) proposes technical assistance to urban local bodies in developing a cluster approach for making the projects viable in the smaller cities, preparation of detail project reports (DPRs) and training programs for project implementation. For the industrial sector, SAP proposes technical assistance for activities required before commercialization of a technology (such as sectoral studies, system integration and clustering concept) and for preparation of training programs (Oyedepo 2014). There is public private partnership scheme. This scheme aims at involving the private sector in setting up of waste-to-energy plants. The municipal corporation which is vested with the function of waste management is not equipped, either financially or technically, to handle the entire system and set up plants to process the waste for conversion to electricity.

Hence, it is envisaged to introduce public private partnership in this sector (Karak et al. 2012). The scheme aims at setting up viable waste-to-energy plants where the municipal solid waste would be processed and output in the form of energy would be generated. The concessionaire would be responsible for setting up the waste-to-energy plant and process the waste by adopting an appropriate technology. The collection of household waste and street sweeping should be separated. The Municipal Corporation should be responsible for collection of waste from street sweeping which should be deposited at designated places. The door-to-door collection of waste from all households should be the responsibility of the concessionaire. The concessionaire may also select suitable material from the waste collected through street sweeping and carry it to its plant. The segregation of waste would also be the responsibility of the concessionaire. This may be done at the household level, intermediate level or plant level.

\subsection{Financial assistance}

Several financial incentives have been offered by government authorities to support WTE technologies and among 
them National Master Plan (NMP) is one of the activities under UNDP/GEF assisted project. It helps in making framework of waste-to-energy program for the country (GEW 2006). Considering Indian communities and conditions, NMP has a prime objective of building capacity to provide additional power generation from the waste released from urban and industrial sectors in a decentralized and costeffective manner through various projects. This approach also meets ongoing adaptation strategies to fulfill implementation needs and is also proved to be environmental friendly by causing reductions in GHG emissions. Thus, it can serve as road maps for most cost-effective implementation plan for the next coming one and half decades.

WTE projects were analyzed financially by assessing their commercial/financial feasibility based upon the generation of potential revenue and the investment cost (Menikpura et al. 2016). It consists of several costs such as operation and maintenance costs, cost of capital, power price and price of other by-products. The NMP recommends the introduction of a credit line for financing the WTE projects. At the central level in India, Ministry of Non-Conventional Energy Sources (MNES), Ministry of Environment and Forest (MoEF) and Ministry of urban development (MoUD) are the nodal ministries involved in formulating the policies and programs for the waste management in the country. There are several international financial institutions and agencies that also fund projects in the energy and environment sectors. A line of credit can be obtained from these institutions through financing agreements between the Government of India and the government of lending country. The Indian Government has also sanctioned the implementation of program on Energy Recovery from Municipal Solid Waste (MSW) during the year 2012-2013. The scheme also provides financial support for establishing five pilot projects for power generation from municipal solid waste.

Five pilot projects on energy recovery from municipal solid waste are to be set up by the help of governmental support with financial support at a rate of Rs. 2.00 crore per MW, a subject to ceiling of $20 \%$ of the project cost and Rs. 10.00 crore per project, whichever is less; the financial assistance is to be provided for the projects that are selected through a clean competitive procedure; also, the financial support of $20 \%$ higher than those specified for different categories would be provided for the projects belonging specifically to the North Eastern Region and Special Category States, namely Himachal Pradesh, J\&K, Sikkim and Uttarakhand; the financial assistance will be released by the Ministry in two installments; the initial of $50 \%$ of the subsidy might be issued depending upon a bank guarantee from any nationalized bank for the exact amount of the bank lending for the project upon providing the $50 \%$ of the sanctioned loan amount (Aswani 2012). It could be treated as an interest free loan up to the release of the second installment of the subsidy. Also if the second installment is not released within a time frame of a year due to noncompletion of the project as per the terms and condition of the sanction, this amount may be refunded by the Bank/FI with interest and paid to MNRE by revoking the bank guarantee. There would be proper agreement with the concerned Bank/FI for recovery of released amount of the subsidy in the case of second installment not being released; within a time of three months after the commencement of the project, the second installment of $50 \%$ of the subsidy may be released and an average of $60 \%$ of the plant load factor (PLF) in between the third month of operation. The quantum of second installment may be reduced by $5 \%$ per month in the event of delay in achieving the average monthly PLF of $60 \%$ (Aswani 2012).

\subsection{Research and development}

Research and development in waste-to-energy sector is not a priority area in most of the developing economies. Vendors bring in technologies, vehicles and equipment from developed countries and try to market them to municipalities, which have no means to ascertain appropriateness of the technologies and suitability of tools and equipment. It is recognized that the cities and state need expert advice while selecting technology as well as while deciding on tools, vehicles and equipment needed. Research and development in this sector to identify appropriate technologies, tools and equipment for use in various levels of city with different quality and quantity of waste generated is therefore considered essential. With an emphasis on India, it is recommended that Indian Institute of Technologies (IITs) and leading scientific institutions be encouraged to take up research projects and programs in this sector, including recycling processes. At least four institutions can be identified one each in north, south, east and west where Centre of Excellence can be set up with Government of India support. This support may be extended for a period of 10 years and budgetary provisions of Rs. 150 crore per institution (total Rs. 600 crore) could be made to support research and development (Planning Commission 2014). These institutions may also undertake $R \& D$ activities on the various processing technologies in vogue, their suitability to Indian conditions in addition to developing new technologies, products, and management practices.

\section{Limitations of WTE technologies}

While developing a waste-to-energy strategy, there are some financial, technical, operational, political and regulatory challenges and opportunities that must be taken into 
account to make any program effective. Practically, this section is an overview of necessary limitation during waste-to-energy program development.

\subsection{Limitation of finance}

Finance is one of the major problems that includes a wide range of costs from preliminary assessments to design and construction. The initial capital investment for digesters, pumping mechanisms, piping, and energy generators are high, making the costs too expensive. Despite these financial limitations, facilities and municipalities have funding opportunities that are outside of the typical financing structure (Wong 2011). There are different government organizations and group that act as a potential source to provide financial support for different stages of the planning process of waste-to-energy conversion. These stages include initial facility audits, feasibility analyses and construction design.

\subsection{Operational challenges}

As the history of WTE technology demonstrates, there are clearly technical challenges that must be overcome for these systems. There is major challenge to manage secondary sludge stemmed from the primary sludge. Odor control is also a problem faced by the New Bedford Wastewater Treatment Plant. The effluents nearly from $50 \%$ of the industries passed from wastewater treatment plant that lead to pungent odors due to the presence of effluent from fish processing industries (Wong 2011). Because of this, the treatment plant should conduct all of its treatment processes either within buildings or below ground. For a plant like New Bedford, where the composition of wastewater and the proximity of the community to the plant pose tight constraints, managing odor can be especially important.

Another challenge for using biogas as energy source is the removal of contaminate from biogas prior to use. Siloxanes, hydrogen sulfides and chlorine are the main contaminants of biogas (Singhal and Eguchi 2011). These contaminants can affect the efficiency and function of this system if they are not removed prior to use as fuel. Production and fluctuations are also a one of concern for treatment plants. Some treatment plants utilize backup natural gas sources to ensure that fluctuations do not detract from the benefit that can be attained from employing a combined heat and power system for onsite power generation. Other operational challenges that complicate the implementation of WTE technologies are struvite remediation (buildup within pipes leading to and from digesters that can constrict flow rates) and foaming in digesters. Furthermore, the opening of new technologies to improve the treatment plant would require new training and processes (AE News 2015).

Further, another challenge is the adaptation of everchanging and increasingly stringent environmental regulations. However, the waste-activated sludge being has been treated by anaerobic digestion but still has high concentrations of the microorganisms that should be treated by improved mechanisms such as cell lysis with ultrasonic treatment. Lastly, concerns have been raised regarding the potential toxicity of the anaerobic digestion by-product if used for land application; ongoing research in this area will be needed to clarify these impacts.

Overcoming the operational challenges is one of the significant problems to convert waste into energy. To obtain the support of the decision makers of a community to implement the strategies, site used needs to be approved by the communities as well as other community.

\subsection{Political challenges}

Political impacts and concerns is one of the important challenges for implementing WTE technologies. Public acceptance is vital for implementation of any WTE projects. There is also challenge in adopting anaerobic digestion and combined heat and power system and management of wastewater treatment plants because of neglecting attitude from concerned government bodies. Particularly, cities face greater problem to make cost-effective decisions as they are profit-maximizing entities, whereas contractors also take their own decision as per their financial interest. Each city has a different system, some wastewater treatment plants responsible to the boards while others responsible to the department of public works. Therefore, there are large numbers of restrictions that have to be regulated before successful implementation of wasteto-energy conversion plan.

\section{Future scenarios}

Management of municipal solid waste is complex in nature and its scientific disposal requires high cost. Applying right waste management strategy for the type of waste generated will serve as the core of municipal solid waste management. For efficient implementation of suitable WTE conversion technology, robust waste stream with cost-effective waste disposal technology is required (Ren et al. 2016). With the advent of new market technologies (such as biomethanation, gasification and pyrolysis) provides different energy routes to recover valuable products from waste. There is continuous improvement in technologies especially in efficiency of the plants, development of new catalysts or enzymes are being developed for lowering the 
environmental and economic costs. These technologies transform the carbon containing waste into marketable fuels. In many cases, the available technologies have shown great potential at small scale and require pilot-scale plants for real-world data. If we want to mitigate climate risk timely, the pace of adoption of waste-to-energy technologies at commercial scale should be accelerated (Gielen et al. 2016). Thus, these technologies have huge potential to serve the goals of sustainability.

\section{Conclusions}

This review aims at finding the potential of waste-to-energy conversion technologies for replacing fossil fuels. It is the need of hour to adopt scientific methods for safe disposal of wastes. The generation of wastes should be minimized by reusing and recycling them. Recovery of energy from wastes is one of the important techniques to mitigate this problem. Along with the recovery of substantial energy; these technologies also lead to a substantial reduction in the overall waste quantities. There are various techniques to convert waste into energy, some of which poses negative impact on environment and human health. Therefore, it is essential to perform LCA analysis of various technologies prior to their implementation.

Acknowledgments Authors are thankful to DST (P-45/18) and ICMR for providing the fund, and the Director and Head, Institute of Environment and Sustainable Development, Banaras Hindu University for providing necessary facilities.

\section{References}

Abbasi T, Abbasi SA (2010) Renewable energy sources: their impact on global warming and pollution. PHI Learning Pvt. Ltd, New Delhi

AE News (2015) Solar power. http://www.alternative-energynews. info/technology/solar-power/. Accessed 14 July 2015

Ahmad AA, Zawawi NA, Kasim FH, Inayat A, Khasri A (2016) Assessing the gasification performance of biomass: a review on biomass gasification process conditions, optimization and economic evaluation. Renew Sustain Energy Rev 53:1333-1347

Ahsan N (1999) Solid waste management plan for Indian megacities. Indian J Environ Prot 19(2):90-95

Ambulkar AR, Shekdar AV (2004) Prospects of biomethanation technology in the Indian context: a pragmatic approach. Resour Conserv Recycl 40(2):111-128

Annepu RK (2012) Sustainable solid waste management in India. Columbia University in the city of New York, Department of Earth and Environmental Engineering, New York

Arafat HA, Jijakli K, Ahsan A (2015) Environmental performance and energy recovery potential of five processes for municipal solid waste treatment. J Clean Prod 105:233-240

Arena U (2012) Process and technological aspects of municipal solid waste gasification. A review. Waste Manag 32(4):625-639
Arena U, Mastellone ML (2009) Fluidized bed gasification of RDF and PDF. AMRA Scientific Report. ISBN 978-88-89972-10-6. www.amracenter.com (in Italian, with an executive summary in English)

Astrup TF, Tonini D, Turconi R, Boldrin A (2015) Life cycle assessment of thermal waste-to-energy technologies: review and recommendations. Waste Manag 37:104-115

Aswani A, Master N, Taneja J, Culler D, Tomlin C (2012) Reducing transient and steady state electricity consumption in HVAC using learning-based model-predictive control. Proc IEEE 100(1):240-253

Balat M (2008) Mechanisms of thermochemical biomass conversion processes, Part 1: reactions of pyrolysis. Energy Source Part A 30(7):620-635

Balat M, Balat H (2009) Recent trends in global production and utilization of bio-ethanol fuel. Appl Energy 86:2273-2282

Belgiorno V, De Feo G, Della Rocca C, Napoli RMA (2003) Energy from gasification of solid wastes. Waste Manag 23:1-15

Bhattacharyya JK, Kumar S, Devotta (2008) Studies on acidification in two-phase biomethanation process of municipal solid waste. Waste Manag 28(1):164-169

Bientinesi M, Petarca L (2009) Comparative environmental analysis of waste brominated plastic thermal treatments. Waste Manag 29:1095-1102

Brammer JG, Lauer M, Bridgwater AV (2006) Opportunities for biomass-derived "bio-oil" in European heat and power markets. Energy Policy 34(17):2871-2880

Braun R, Laaber M (2007) Efficiency of energy crop digestion: evaluation of 41 full scale biogas plants in Austria. Institute for Environmental Biotechnology, Vienna

Bridgwater AV (2003) Renewable fuels and chemicals by thermal processing of biomass. Chem Eng J 91(2):87-102

Brunner PH, Rechberger H (2015) Waste to energy-key element for sustainable waste management. Waste Manag 37:3-12

Buekens A, Cen K (2011) Waste incineration, PVC, and dioxins. J Mater Cycles Waste 13(3):90-197

CEWEP (2011) Environmentally sound use of bottom ash. www. cewep.eu

Chaiprasert P (2011) Biogas production from agricultural wastes in Thailand. J Sustain Energy Environ Special Issue 63:65

Chakrabarti $T$ (2014) Emergence of green technologies towards sustainable growth. In: Environment and sustainable development. Springer, India, pp 1-21

Chaubey R, Sahu S, James OO, Maity S (2013) A review on development of industrial processes and emerging techniques for production of hydrogen from renewable and sustainable sources. Renew Sustain Energy Rev 23:443-462

Cheng H, Hu Y (2010) Municipal solid waste (MSW) as a renewable source of energy: current and future practices in China. Bioresour Technol 101(11):3816-3824

Cherubini F, Bargigli S, Ulgiati S (2009) Life cycle assessment (LCA) of waste management strategies: landfilling, sorting plant and incineration. Energy 34(12):2116-2123

Chu S, Majumdar A (2012) Opportunities and challenges for a sustainable energy future. Nature 488(7411):294-303

Consonni S, Giugliano M, Grosso M (2005) Alternative strategies for energy recovery from municipal solid waste: part A: mass and energy balances. Waste Manag 25(2):123-135

Coombs J (1996) Bioconversion assessment study. CPL Scientific Ltd., UK, Air-CT92-8007

D'Alisa G, Di Nola MF, Giampietro M (2012) A multi-scale analysis of urban waste metabolism: density of waste disposed in Campania. J Clean Prod 35:59-70

Dedinec A, Markovska N, Ristovski I, Velevski G, Gjorgjievska VT, Grncarovska TO, Zdraveva P (2015) Economic and 
environmental evaluation of climate change mitigation measures in the waste sector of developing countries. J Clean Prod $88: 234-241$

Defra (2007) Advanced biological treatment of municipal solid waste. Department for Environment, Food and Rural Affairs (Defra). www.defra.gov.uk

Demirbas A (2007) Producing bio-oil from olive cake by fast pyrolysis. Energy Source Part A Recovery Util Environ Effects 30(1):38-44

Demirbas A (2009) Fuel properties of pyrolysis oils from biomass. Energy Source Part A 31(5):412-419

Demirbas MF, Balat M, Balat H (2011) Biowastes-to-biofuels. Energy Convers Manag 52(4):1815-1828

DiBlasi C (2000) Dynamic behavior of stratified downdraft gasifier. Chem Eng Sci 55:2931-2944

Divya D, Gopinath LR, Christy PM (2015) A review on current aspects and diverse prospects for enhancing biogas production in sustainable means. Renew Sustain Energy Rev 42:690-699

E4tech (2009). Review of technologies for gasification of biomass and wastes. NNFCC project 98/008. www.nnfcc.co.uk

Eddine BT, Salah MM (2012) Solid waste as renewable source of energy: current and future possibility in Algeria. Int J Energy Environ Eng 3(1):1-12

Embrandiri A, Quaik S, Rupani P, Srivastava V, Singh P (2015) Sustainable utilization of oil palm wastes: opportunities and challenges. In: Singh RP, Sarkar A (eds) Waste management. Nova Science Publishers, New York, pp 231-246

Eriksson O, Bisaillon M, Haraldsson M, Sundberg J (2016) Enhancement of biogas production from food waste and sewage sludge-environmental and economic life cycle performance. J Environ Manag 175:33-39

Farrell AE, Zerriffi H, Dowlatabadi H (2004) Energy infrastructure and security. Annu Rev Environ Resour 21(29):421-469

Fruergaard T, Ekvall T, Astrup T (2009) Energy use and recovery in waste management and implications for accounting of greenhouse gases and global warming contributions. Waste Manag Res 27(8):724-737

Gaeta-Bernardi A, Parente V (2016) Organic municipal solid waste (MSW) as feedstock for biodiesel production: a financial feasibility analysis. Renew Energy 86:1422-1432

Ghiani G, Laganà D, Manni E, Musmanno R, Vigo D (2014) Operations research in solid waste management: a survey of strategic and tactical issues. Comput Oper Res 44:22-32

Gielen D, Boshell F, Saygin D (2016) Climate and energy challenges for materials science. Nat Mater 15(2):117-120

Guerrero LA, Maas G, Hogland W (2013) Solid waste management challenges for cities in developing countries. Waste Manag 33(1):220-232

Gunamantha M, Sarto (2012) Life cycle assessment of municipal solid waste treatment to energy options: case study of KARTAMANTUL region, Yogyakarta. Renew Energy 41:277-284

Hawkey D, Webb J, Winskel M (2013) Organisation and governance of urban energy systems: district heating and cooling in the UK. J Clean Prod 50:22-31

Hay JX, Wu TY, Juan JC (2013) Biohydrogen production through photo fermentation or dark fermentation using waste as a substrate: overview, economics, and future prospects of hydrogen usage. Biofuel Bioprod Biorefin 7(3):334-352

Heermann C, Schwager FJ, Whiting KJ (2000) Pyrolysis and gasification of waste: a worldwide technology and business review. Technologies and Processes, 2nd edn. Juniper Consultancy Services Limited, Uley

Hegde U, Chang TC, Yang SS (2003) Methane and carbon dioxide emissions from Shan-chu-ku landfill site in northern Taiwan. Chemosphere 52:1275-1285
Huang H, Liu H, Gan YR (2010) Genetic modification of critical enzymes and involved genes in butanol biosynthesis from biomass. Biotechnol Adv 28:651-657

http://waste-management-world.com/a/the-future-of-wte-the-newwaste-to-energy-developments-that-will-change-the-industry

Iakovou E, Karagiannidis A, Vlachos D, Toka A, Malamakis A (2010) Waste biomass-to-energy supply chain management: a critical synthesis. Waste Manag 30(10):1860-1870

IEA, International Energy Agency (2006) World energy outlook. IEA, Paris

IEA, International Energy Agency (2008) World energy outlook. OECD/IEA, Paris

IEA, International Energy Agency (2010) World energy outlook. OECD/IEA, Paris

IEA (2014) Key world energy statistics. IEA, Paris

International Solid Waste Association (ISWA) (2002) Industry as a partner for sustainable development. ISWA and United Nation Environment Program (UNEP), Copenhagen

ISWA (2006) Management of bottom ash from WTE plants, ISWAWG thermal treatment subgroup bottom ash from WTE-plants. www.iswa.org

Johnke B (2012) Emissions from waste incineration. Good practice guidance and uncertainty management in national greenhouse gas inventories, IPCC. http://www.ipcc-nggip.iges.or.jp/public/ gp/bgp/5_3_Waste_Incineration.pdf. pp 455-468

Johri R, Rajeshwari KV, Mullick AN (2011) Technological option for municipal solid waste management. In: Wealth from waste: trends and technologies. The Energy and Research Institute, New Delhi

Kalyani KA, Pandey KK (2014) Waste to energy status in India: a short review. Renew Sustain Energy Rev 31:113-120

Karak T, Bhagat RM, Bhattacharyya P (2012) Municipal solid waste generation, composition, and management: the world scenario. Crit Rev Environ Sci Technol 42(15):1509-1630

Katyal S (2007) Effect of carbonization temperature on combustion reactivity of bagasse char. Energy Sources Part A 29(16): $1477-1485$

Khalid A, Arshad M, Anjum M, Mahmood T, Dawson L (2011) The anaerobic digestion of solid organic waste. Waste Manag 31(8):1737-1744

Khatiwada D, Seabra J, Silveira S, Walter A (2012) Power generation from sugarcane biomass-a complementary option to hydroelectricity in Nepal and Brazil. Energy 48(1):241-254

Khoo HH (2009) Life cycle impact assessment of various waste conversion technologies. Waste Manag 29(6):1892-1900

Knoef H (2005) Practical aspects of biomass gasification. In: Handbook of biomass gasification, pp 13-37. BTG-Biomass Technology Group (BTG), ISBN: 90-810068-1-9. Enschede, The Netherlands

Kumar S (2000) Technology options for municipal solid waste-toenergy project. TERI Inf Monit Environ Sci 5:1-11

Lal AK (1998) Environmental status of Delhi. Indian J Environ Prot 16(I):I-II

Liu W, Lund H, Mathiesen BV, Zhang X (2011) Potential of renewable energy systems in China. Appl Energy 88(2):518-525

Long H, Li X, Wang H, Jia J (2013) Biomass resources and their bioenergy potential estimation: a review. Renew Sustain Energy Rev 26:344-352

Mabee WE, Saddler JN (2010) Bioethanol from lignocellulosics: status and perspectives in Canada. Bioresour Technol 101:4806-4813

Mastellone ML, Santoro D, Zaccariello L, Arena U (2010) The effect of oxygen-enriched air on the fluidized bed co-gasification of coal, plastics and wood. In: 3rd international symposium on energy from biomass and waste, Venice, Italy, 8-11 November, 2010. CISA Publisher, Italy-ISBN 978-88-6265-008-3 
McKay G (2002) Dioxin characterisation, formation and minimisation during municipal solid waste (MSW) incineration: review. Chem Eng J 86(3):343-368

McKendry P (2002) Energy production from biomass (part 1): overview of biomass. Bioresour Technol 83(1):37-46

Menikpura SNM, Sang-Arun J, Bengtsson M (2016) Assessment of environmental and economic performance of waste-to-energy facilities in Thai cities. Renew Energy 86:576-584

Minghua Z, Xiumin F, Rovetta A, Qichang H, Vicentini F, Bingkai L, Yi L (2009) Municipal solid waste management in Pudong New Area, China. Waste Manag 29(3):1227-1233

Mohammed YS, Mustafa MW, Bashir N, Mokhtar AS (2013) Renewable energy resources for distributed power generation in Nigeria: a review of the potential. Renew Sustain Energy Rev 22:257-268

Mohan D, Pittman CU, Steele PH (2006) Pyrolysis of wood/biomass for bio-oil: a critical review. Energy Fuel 20(3):848-889

Murphy JD, McKeogh E (2004) Technical, economic and environmental analysis of energy production from municipal solid waste. Renew Energy 29(7):1043-1057

Murphy JD, McKeogh E (2006) The benefits of integrated treatment of wastes for the production of energy. Energy 31(2):294-310

Münster M, Meibom P (2011) Optimization of use of waste in the future energy system. Energy 36(3):1612-1622

Mwirigi J, Balana BB, Mugisha J, Walekhwa P, Melamu R, Nakami S, Makenzi P (2014) Socio-economic hurdles to widespread adoption of small-scale biogas digesters in Sub-Saharan Africa: a review. Biomass Bioenergy 70:17-25

Nakakubo T, Tokai A, Ohno K (2012) Comparative assessment of technological systems for recycling sludge and food waste aimed at greenhouse gas emissions reduction and phosphorus recovery. J Clean Prod 32:157-172

Ng WPQ, Lam HL, Ng FY, Kamal M, Lim JHE (2012) Waste-towealth: green potential from palm biomass in Malaysia. J Clean Prod 34:57-65

Norway S (2008) Natural resources and the environment. Statistics Norway. ssb.no/english/subjects/01/sa_nrm/nrm2008/sa109.pdf

Ntaikou I, Antonopoulou G, Lyberatos G (2010) Biohydrogen production from biomass and wastes via dark fermentation: a review. Waste Biomass Valor 1:21-39

Oh TH, Pang SY, Chua SC (2010) Energy policy and alternative energy in Malaysia: issues and challenges for sustainable growth. Renew Sustain Energy Rev 14(4):1241-1252

Ouda OK, Cekirge HM, Raza SA (2013) An assessment of the potential contribution from waste-to-energy facilities to electricity demand in Saudi Arabia. Energy Convers Manag 75:402-406

Oyedepo SO (2014) Towards achieving energy for sustainable development in Nigeria. Renew Sustain Energy Rev 34:255-272

Oyewole OA (2010) Biogas production from chicken droppings. Sci World J 5(4):11-14

Pan SY, Du MA, Huang IT, Liu IH, Chang EE, Chiang PC (2015) Strategies on implementation of waste-to-energy (WTE) supply chain for circular economy system: a review. J Clean Prod 108:409-421

Panepinto D, Blengini GA, Genon G (2015) Economic and environmental comparison between two scenarios of waste management: MBT vs thermal treatment. Resour Conserv Recycl 97:16-23

Peng J, Chen P, Lou H, Zheng X (2009) Catalytic upgrading of bio-oil by HZSM-5 in sub-and super-critical ethanol. Bioresour Technol 100(13):3415-3418

Planning Commission (2014) Report of the expert group on estimation of proportion and number of poor (No. id: 5627)

Psomopoulos CS, Bourka A, Themelis NJ (2009) Waste-to-energy: a review of the status and benefits in USA. Waste Manag 29:1718-1724
Purohit P, Michaelowa A (2007) CDM potential of bagasse cogeneration in India. Energy Policy 35(10):4779-4798

Pütün AE (2002) Biomass to bio-oil via fast pyrolysis of cotton straw and stalk. Energy Sources 24(3):275-285

Raghubanshi AS, Singh RP, Sharma B (2013) Biomass to energy. A bi-monthly newsletter of the Ministry of New and Renewable Energy, Government of India, vol 6, Akshay Urja , pp 13-15

Ramachandra T (2006) Management of municipal solid waste. Capital Publishing Company, New Delhi

Ramachandra T, Varghese S (2003) Exploring possibilities of achieving sustainability in solid waste management. Indian $\mathbf{J}$ Environ Health 45(4):255-264

Rao PV, Baral SS, Deya R, Mutnuri S (2010) Biogas generation potential by anaerobic digestion for sustainable energy development in India. Renew Sustain Energy Rev 14:2086-2094

Rechberger H, Schöller G (2006) Comparison of relevant air emissions from selected combustion technologies. In: Project CAST. CEWEP-Congress, Waste-to-Energy in European Policy, vol 18

Reddy S, Galab S (1998) An integrated economic and environmental assessment of solid waste management in India-the case of Hyderabad, India. A report, Centre for Economic and Social Studies, Andhra Pradesh, India

Ren X, Che Y, Yang K, Tao Y (2016) Risk perception and public acceptance toward a highly protested waste-to-energy facility. Waste Manag 48:528-539

Richard M (2012) Global waste-to-energy market to reach $\$ 29.2$ Billion by 2022. http://www.navigantresearch.com/newsroom/ global-waste-to-energy-market-to-reach-29-2-billion-by-2022

Rigamonti L, Sterpi I, Grosso M (2016) Integrated municipal waste management systems: an indicator to assess their environmental and economic sustainability. Ecol Indic 60:1-7

RIS International (2005) Feasibility of generating green power through anaerobic digestion of garden refuse from the Sacramento area. Feasibility study. RIS International, Sacramento Municipal Utility District, Sacramento

Saini S, Rao P, Patil Y (2012) City based analysis of MSW to energy generation in India, calculation of state-wise potential and tariff comparison with EU. Proc Soc Behav Sci 31(37):407-416

Samaras P, Karagiannidis A, Kalogirou E, Themelis N, Kontogianni St (2010) An inventory of characteristics and treatment processes for fly ash from waste-to-energy facilities for municipal solid wastes. In: 3rd international symposium on energy from biomass and waste, Venice, Italy, 8-11 November, 2010. CISA Publisher, Italy. ISBN 978-88-6265-008

Sarkar N, Ghosh SK, Bannerjee S, Aikat K (2012) Bioethanol production from agricultural wastes: an overview. Renew Energy 37:19-27

Sarkar A, Singh J (2010) Financing energy efficiency in developing countries-lessons learned and remaining challenges. Energy Policy 38(10):5560-5571

Scarlat N, Dallemand JF, Monforti-Ferrario F, Banja M, Motola V (2015a) Renewable energy policy framework and bioenergy contribution in the European Union-an overview from national renewable energy action plans and progress reports. Renew Sustain Energy Rev 51:969-985

Scarlat N, Motola V, Dallemand JF, Monforti-Ferrario F, Mofor L (2015b) Evaluation of energy potential of municipal solid waste from african urban areas. Renew Sustain Energy Rev 50:1269-1286

Sen B, Aravind J, Kanmani P, Lay CH (2016) State of the art and future concept of food waste fermentation to bioenergy. Renew Sustain Energy Rev 53:547-557

Sharholy M, Ahmad K, Mahmood G, Trivedi RC (2008) Municipal solid waste management in Indian cities-a review. Waste Manag 28(2):459-467 
Sharma RK, Bakhshi NN (1993) Catalytic upgrading of pyrolysis oil. Energy Fuel 7(2):306-314

Shaw M (2006) Pyrolysis of lignocellulosic biomass to maximize biooil yield: an overview. In: 2006 ASAE annual meeting. American Society of Agricultural and Biological Engineers, p 1

Shih TS, Chen HL, Wu YL, Lin YC, Lee CC (2006) Exposure assessment of polychlorinated dibenzo-p-dioxins and dibenzofurans $(\mathrm{PCDD} / \mathrm{Fs})$ in temporary municipal-waste-incinerator maintenance workers before and after annual maintenance. Chemosphere 64:1444-11449

Singh A, Pant D, Korres NE, Nizami AS, Prasad S, Murphy JD (2010) Key issues in life cycle assessment of ethanol production from lignocellulosic biomass: challenges and perspectives. Bioresour Technol 101:5003-5012

Singh RP, Singh P, Araujo AS, Ibrahim MH, Sulaiman O (2011a) Management of urban solid waste: vermicomposting a sustainable option. Resour Conserv Recycl 55(7):719-729

Singh RP, Tyagi VV, Allen T, Ibrahim MH, Kothari R (2011b) An overview for exploring the possibilities of energy generation from municipal solid waste (MSW) in Indian scenario. Renew Sustain Energy Rev 15(9):4797-4808

Singhal SC, Eguchi K (2011) Solid oxide fuel cells 12 (SOFC XII), vol 35, no 1

Skovgaard M, Hedal N, Villanueva A, Møller Andersen F, Larsen HV (2008) Municipal waste management and greenhouse gases. European Topic Centre on Resource and Waste Management

Soo CS, Yap WS, Hon WM, Phang LY (2015) Mini review: hydrogen and ethanol co-production from waste materials via microbial fermentation. World J Microbiol Biotechnol 31(10):1475-1488. doi:10.1007/s11274-015-1902-6

Sovacool BK (2009) The importance of comprehensiveness in renewable electricity and energy-efficiency policy. Energy Policy 37:1529-1541

Srivastava V, Ismail SA, Singh P, Singh RP (2015) Urban solid waste management in the developing world with emphasis on India: challenges and opportunities. Rev Environ Sci Biotechnol 14:317-337

Steiner A (2010) Focusing on the good or the bad: what can international environmental law do to accelerate the transition towards a green economy. Am U Int'l L Rev 843:843-875

Suhaimi SN, Phang LY, Maeda T, Abd-Aziz S, Wakisaka M, Shirai Y, Hassan MA (2012) Bioconversion of glycerol for bioethanol production using isolated Escherichia coli SS1. Braz J Microbiol 43(2):506-516

Tayde P (2012) Creating wealth from organic waste. Akshay Urja $5(6): 38-40$

Tchobanoglous G, Burton FL, Stensel HD (2004) Wastewater engineering: treatment and reuse, 4th edn. McGraw Hill, New York

Thamburaj R (2000) Fast pyrolysis of biomass for green power generation. In: First world conference and exhibition on biomass for energy and industry, Sevilla, Spain, June 5-9

Themelis NJ (2003) An overview of the global waste-to-energy industry. Waste Manag World 40-48
Tozlu A, Özahi E, Abuşoğlu A (2016) Waste to energy technologies for municipal solid waste management in Gaziantep. Renew Sustain Energy Rev 54:809-815

Trzcinski AP, Stuckey DC (2010) Treatment of municipal solid waste leachate using a submerged anaerobic membrane bioreactor at mesophilic and psychrophilic temperatures: analysis of recalcitrants in the permeate using GC-MS. Water Res 44:671-680

Tsai WT, Kuo KC (2010) An analysis of power generation from municipal solid waste (MSW) incineration plants in Taiwan. Energy 35(12):4824-4830

UCR-University of California Riverside (2009) Evaluation of emissions from thermal conversion technologies processing municipal solid waste and biomass. Final report for bioenergy producers ass. www. bioenergyproducers.org/documents/ucr_emissions_report.pdf

US-EPA Environmental Protection Agency (2003) Letter to President of integrated waste service association. www.wte.org/docs/ epaletter.pdf

Vaish B, Singh P, Kothari R, Srivastava V, Singh PK, Singh RP (2016) The potential of bioenergy production from marginalized lands and its effect on climate change. Clim Change Environ Sustain 4(1):7-13

Vispute TP, Huber GW (2009) Production of hydrogen, alkanes and polyols by aqueous phase processing of wood-derived pyrolysis oils. Green Chem 11(9):1433-1445

Wang L, Templer R, Murphy RJ (2012) A life cycle assessment (LCA) comparison of three management options for waste papers: bioethanol production, recycling and incineration with energy recovery. Bioresour Technol 120:89-98

White W, Lunnan A, Nybakk E, Kulisic B (2013) The role of governments in renewable energy: the importance of policy consistency. Biomass Bioenergy 57:97-105

Wiesenthal T, Mourelatou A (2006) How much bioenergy can Europe produce without harming the environment?

Wong SC (2011) Tapping the energy potential of municipal wastewater treatment: anaerobic digestion and combined heat and power in Massachusetts. Massachusetts Department of Environmental Protection. Accessed 5 July 2012

World Bank (1999) What a waste: solid waste management in Asia. Urban development sector unit East Asia and Pacific region. www.worldbank.org/urban/solid_wm/erm/CWG\%20folder/uwp1. pdf

World Bank (2012) What a waste: a global review of solid waste management. Urban development series knowledge papers. http://siteresources.worldbank.org/INTURBANDEVELOPMENT/ Resources/336387-1334852610766/What_a_Waste2012_Final.pdf

World Bank Technical Guidance Report (1999) Municipal solid waste incineration library of congress cataloging-in-publication data

Yelda S, Kansal S (2003) Economic insight into MSWM in Mumbai: a critical analysis. Int J Environ Pollut 19(5):516-527

Zsigraiová Z, Tavares G, Semiao V, de Graça Carvalho M (2009) Integrated waste-to-energy conversion and waste transportation within island communities. Energy 34(5):623-635

Zuberi MJS, Ali SF (2015) Greenhouse effect reduction by recovering energy from waste landfills in Pakistan. Renew Sustain Energy Rev 44:117-131 